\title{
THE STATUTE OF LIMITATIONS IN TAX CASES AND MISTAKEN ADVICE BY OFFICIALS*
}

THE statute of limitations on federal tax claims must balance conflicting equities of individual taxpayers and the public. Whenever the statute bars collection of a valid claim, the taxpayer receives a windfall at the public's expense. On the other hand, if the government asserts tax claims many years after they arise, individuals who in good faith believed they owed no tax may suffer unreasonable hardship. Accordingly, Congress has provided a relatively short limitations period if the taxpayer files a proper return. ${ }^{1}$ But if no return is filed, the government is free to sue at any time after it discovers a deficiency. ${ }^{2}$

The case of Stockstrom v. Commissioner ${ }^{3}$ presented a situation where this limitation rule appeared to work considerable injustice to the taxpayer. In 1938 taxpayer made gifts to certain trusts. Relying on previous determina-

*Stockstrom v. Commissioner, 190 F.2d 283 (D.C. Cir. 1951).

1. Estate and gift taxes must be assessed within three years from the date of filing. INT. REv. CODE $\S \S 874(\mathrm{a}), 1016$ (a). The same period is prescribed for income taxes, INT. Rev. CoDE $\$ 275(\mathrm{a})$, tuless there is an omission in excess of $25 \%$ of the gross stated income. If such an omission exists, a five-year period is provided for assessment, INT. REv. CODE $\S 275(\mathrm{c})$, regardless of taxpayer's motives or intention. O'Brien v. Commissioner, 148 F.2d 456 (9th Cir. 1945); Ewald v. Commissioner, 141 F.2d 750 (6th Cir. 1944). See Hadley, Deficiencies Under $\$ 275(c), 27$ Taxrs 464 (1949).

Proceedings for collection must begin within six years of assessment. INT. REv. Coov $\S \S 276$ (c) (income tax), 874(b)(2) (estate tax), and 1016(b)(2) (gift tax).

Taxpayers may waive the limitations period in income tax questions. INT. Rtv. Cons: $\S 276$ (b) and (c) ; Florsheim Bros. Co. v. United States, 280 U.S. 453, 466 (1930). A waiver reinstates tax liability if given after the limitations period expires, Helveriny v. Newport Co., 291 U.S. 485 (1934), even if given by mistake, Clifton Mfg.. Co. v. United States, 76 F.2d 577 (4th Cir. 1935). See Emmanuel, The Effcct of Waivcrs in Fcdcral Income Tax Cases, 3 U. of FLA. I. Rev. 176, 184 (1950).

The statutes do not provide for the extension of the limitations period for estate and gift taxes by the use of consent waivers. Hence if the government's claim is about to be barred by limitations, the Bureau will send a deficiency letter to protect the government's claim to taxes. GoOdrich \& REDMAN, PROCEDURe BeFore tHe Bureau of INTERHAL REVENuE 49 (1951).

2. "In the case of false or fraudulent return with intent to evade tax or of a failure to file a return the tax may be assessed, or a proceeding for the collection of such tax may be begun without assessment, at any time." INT. REv. CoDE \$\$ 276(a) (income tax), 874(b) (estate tax), and 1016(b) (1) (gift tax). See, e.g., Southern Md. Ag. v. Commissioner, 40 B.T.A. 549 (1939) (Commissioner reversed earlier ruling and collected taxes for period 1921-1935). See also 2 Paun, Federal Estate and Gift Taxation 1026 (1942).

In addition to losing the benefits of the limitations period, taxpayers who fail to file a return may be punished by up to one year in jail or a $\$ 10,000$ fine. INT. Rev. Cove $\S 145(\mathrm{a})$.

3. 190 F.2d 283 (D.C. Cir. 1951). 
tions that similar gifts were entitled to an exclusion, he filed no return in 1938. In 1941 a revenue agent noticed that no return had been filed and notified the taxpayer. The agent and the taxpayer then consulted the Estate and Gift Tax section-head in St. Louis. This official said that no tax was due, and hence no return was necessary. After this assurance taxpayer took no further action. In 1948, following a change in statutory interpretation, the Commissioner assessed a deficiency against the taxpayer's estate for taxes due on the 1938 gifts. ${ }^{4}$ The Tax Court held that the taxpayer's failure to file a return prevented the statute of limitations from running, and adjudged the estate liable for the deficiency plus a penalty. ${ }^{\circ}$

On appeal the Court of Appeals for the District of Columbia reversed, holding that the government was barred from collecting its claim. ${ }^{B}$ The Court considered it unjust to allow the government to found a claim on an omission induced by its agent. ${ }^{7}$ Further, the Court found that, although no return had been filed, the purpose of the filing requirement was here fulfilled, since in 1941 the government possessed all pertinent facts. Finally, the Court declared that the Internal Revenue Code obligates the Collector, if he has sufficient information, to file returns for taxpayers who fail to do so. ${ }^{8}$ The court therefore held that the statute of limitations began to run at the time the Collector should have made a return.

4. The Section in question was $\S 504$ (b), Revenue Act of 1932, 47 Stat. 247 (1932), 26 U.S.C.A. Int. Rev, Acts 585 (1940). Gifts in trust were specifically denied the exclusion by $\$ 505$ (b), Revenue Act of 1938. 52 Stat. 565 (1938), 26 U.S.C.A. Int. Rev. Acts 1139 (1940).

5. The Tax Court opinion is concerned primarily with the question of whether the beneficiaries received present interests when gifts were made to the trusts. Since the trust agreements were not introduced in evidence, the court held it had no choice but to rule that the gifts were future interests. Stockstrom v. Commissioner, 14 T.C. 652 (1950).

6. Stockstrom v. Commissioner, 190 F.2d 283 (D.C. Cir. 1951).

7. The court relied on Balkan Nat. Ins. Co. v. Commissioner, 101 F.2d 75 (2d Cir. 1939) (taxpayer unable to file return because records were seized by the Government), and on statement by Mir. Justice Cardozo: "Sometimes the resulting disability has tsen characterized as estoppel, sometimes as a waiver. . . Enough for present purposes that the disability has its roots in a principle more nearly ultimate than either waiver or estoppel, the principle that no one shall be permitted to found any claim upon his own inequity or take advantage of his own wrong." Stearns Co. v. United States, 291 U.S. 54, 61-2 (1933). The Stearzis decision has been criticized for its vagueness. Maguire \& Zimet, Hobson's Choice in Federal Taxation, 48 HARv. L. REv. 1231, 1298 (1935).

8. Stockstrom v. Commissioner, 190 F.2d 283, 289 (D.C. Cir. 1951). This ruling was based on INT. REv. CoDE § 3612: "(a) Authority of collector. If any person fails to make and file a return or list at the time prescribed by law or by regulation made under authority of law, or makes, wilifully or othervise a false or fraudulent return or list, the Collector or deputy collector shall make the return or list from his own knowledge and from such information as he can obtain through testimony or otherwise. . . .

"(c) Legal status of returns. Any returns or list so made and sulserited by the Commissioner, or by a collector or deputy collector and approved by the Commissioner, shall be prima facie good and sufficient for all legal purpuses." 
Although the result in Stockstrom may appear equitable, the Court's reasoning, if followed, could have unfortunate effects on the nation's tax-collection system. In allowing the assurance of a regional official in effect to bind the government, the Court overlooked the fact that in this case only Bureatu officials in Washington had authority to make a final determination of tax liability. 9 Review procedures of the Bureau of Internal Revenue would be ineffectual if taxpayers could legally rely on lower officials' opinions. Moreover, in tax cases the government has generally been held not bound by the acts of its agents, and taxpayers are on notice that opinions and advice of officials are subject to change. ${ }^{10}$ Even the formal written rulings of the Commissioner are not binding. ${ }^{11}$ This rule not only safeguards review procedures

9. In 1940 , collectors retained for final audit income tax returns of $\$ 5000$ or less, some estate tax returns, and information returns from partnerships and fiduciaries. All other returns were transmitted to the Washington office of the Bureau. Rep. ATr'Y GLN. Comm. Ad. Proc., Mono. 22, p. 20 (1940). Final audit of $80 \%$ of gift tax returns toole place in Washington. Difficult cases were returned to revenue agents for a ficld audit on taxpayer's premises. Id. at 22 . Every audit resulted in a formal report reviewed by the field office with a second audit review held in Washington. Id. at 27. Shortly prior to December 31, 1947, the collector sent all individual income tax returns in excess of $\$ 7000$ and all corporation returns in excess of $\$ 25,000$ to the Washington office. Gcommicr \& Redaran, Procedures Before the Bureau of Internal Revenue 45 (1951).

Today all gift and estate tax returns are investigated and audited by ficld forces of the Income Tax Unit. These are, however, subject to review by the Miscellaneous Tax Unit in Washington. The Work and Jurisdiction of the Bureau of Internal Revenue 103 (1948). As of March 1, 1951, the Miscellaneous Tax Unit has been known as the Excise Tax Unit. Goodrich \& ReDMaN, op. cit. supra, at 159 (Table I).

A detailed presentation of contemporary channels of review may be found in 26 Cous FED. REGS. $\$ \S 601.27(\mathrm{~b})(2)$ and 601.28 (estate and gift tax), $\S 601.13$ (income tax) (1949).

10. "Whoever deals with the Government does so with notice that no agent can by neglect or acquiescence commit it to an erroneous interpretation of the law." Shafer $v$. Helvering, 83 F.2d 317, 320 (D.C. Cir. 1936), aff'd, 299 U.S. 171 (1936) (certiorari granted on another issue).

See Ritter v. United States, 28 F.2d 265 (3rd Cir. 1928) ; Stewart v. United Statey, 24 F. Supp. 145 (N.D. Cal. 1938) ; Keystone Automobile Club Casualty Co. v. Commissioner, 40 B.T.A. 291, 306 (1939). See Prettyman, J. dissenting in Stockstrom v, Commissioner, 190 F.2d 283, 289 (D.C. Cir. 1951). See generally Atlas, Doctrinte of Estoppel in Tax Cases, 3 TAX L. Rev. 71, 79 (1947-48); 10A MerTENs, LAW of FederRAL InCOME TAXATION 193 (1948).

Some cases which may appear to be examples of estoppel are actually situations where the Commissioner is forced by the courts to elect between courses of action. Eichelbcrger v. Commissioner, 88 F.2d 874 (5th Cir. 1937); Earnest Strong v. Commissioner, 7 T.C. 953 (1946) (Commissioner, having succeeded in assessing income taxes on a transaction, may not later say that the same transaction was a gift in order to collect increased tax). On the doctrine of election in tax cases, see Maguire \& Zimet, Hobson's Choicc in Federal Taxation, 48 HARv. L. REv. 1281, 1285 (1935).

The Government, on the other hand, finds little difficulty in ciaiming estoppel against taxpayers. Ibid; Atlas, Doctrine of Estoppel in Tax Cases, 3 TAx L. Rev. 71, 72 (1947-48).

11. The classic case is James Couzens, 11 B.T.A. 1040 (1928). At taxpayer's request the Commissioner prepared an estimate of the approximate tax on a proposed sale of Ford 
but also prevents officials from making final determinations of statutory questions that should be decided by the courts. ${ }^{12}$ Ordinarily no substantial injustice results if an erroneous ruling in favor of a taxpayer is reversed, since he will be liable only for his legal obligation plus accrued interest. Though a

stock and inclosed it in a formal letter to the taxpayer. Relying on the government valuation, the sale was made and the tax paid. Five days before the statute of limitations ran, a new Commissioner reversed his predecessor and claimed ten million dollars in additional taxes. The Board of Tax Appeals held that the letter did not bind the Commissioner. See also Mit. Vernon Trust Co. v. Commissioner, 75 F.2d 938 (2d Cir. 1935) (no estoppel arises against the Commissioner for accepting returns as correct) ; Stewart v. United States, 24 F. Supp. 145 (N.D. Cal. 1938) (ruling of the Commissioner will not set at naught a statute of the United States); Southern MId. Ag. v. Commissioner, 40 B.T.A. 549 (1939).

During the fiscal year 1951, approximately 68,000 income tax rulings were made by the Income Tax Division of the Bureau. The fact that these rulings have no binding effect is not stated in the "ruling letter" which the taxpayer receives. Communication to the Yale Law Journal from E. I. McLarney, Deputy Commissioner of Internal Revenue, dated May 15 , 1952, on file in Yale Law Library.

Although letter rulings do not legally bind the Commissioner, they are usually followed as a matter of practice. Wenchel, Taxpayers' Rulings, 5 TAX L. REv. 105, 114

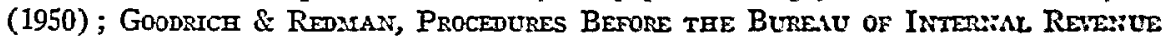
124 (1951).

12. "A contrary ruling [estoppel by reason of Commissioner's letter] would mean that a taxing official who, as a courtesy to a taxpayer, rendered him aid in such a situation, would thereby and to that extent effectively tie his official hands and render himself impotent to perform the duties placed on him by the taxing statutes. . . . The successful accomplishment of [estoppel] ... would so effectually circumscribe the povers of review vested by law in the Commissioner as to defeat the well considered purpose of the law: ..." Van Fossan, J., concurring in James Couzens, 11 B.T.A. 1040, 1174 (1928).

The undesirability of allowing minor officials to bind the government is far more pronounced when the applicable law is unsettled. For example, in the principal case, the law as to the taxability of such gifts was doubtful from 1910, when there was a conflict between the Fifth and Seventh Circuits, until March 3, 1941, when the conflict was resolved in Helvering v. Hutchins, 312 U.S. 393 (1941) (holding the beneficiaries of the trusts to be the true donees). In the principal case, it is uncertain from the briefs and from the decision whether the opinion of the agent was given before or after the Hutchiss decision.

An exception to the rule is made by INr. REv. ConE $\$ 3760$, which authorizes the Commissioner to enter binding closing agreements with taxpayers. The Commissioner vill not enter such an agreement if the question is controversial or in litigation. Nor will an agreement be reached if a similar agreement would be required for a large number of separate taxpayers on the same subjects and facts. Atlas, Doctrine of Estopfel is Tax Cases, 3 TAX L. KEv. 82, 83 (1947-48). For procedures, see 26 CoDE FED. REGs. $\$ \$ 462.1$, 601.4(b) (1949).

INT. REv. CoDE $\$ 3761$ authorizes binding compromises if approved by the Secretary or Under Secretary of the Treasury. These compromises must be made before referral of the case to the Department of Justice. Once the case is referred, the Attorney General may compromise. See 26 Code Fed. Regs. \$ 601.4(c) (1949); Kamens \& Ancier, Ciril Offers in Compromise, 28 TAxes 427 (1950).

The status of informal closing agreements, unauthorized by statute, is unsettled. Guggenheim v. United States, 77 F. Supp. 186 (Ct. Cl. 1948), cert. deried, 335 U.S. 911 (1949) (agreement upheld); but cf. Eotany Worsted v. United States, 278 U.S. 282 (1920) (agreement overthrown and statutory means held exclusive.); Joyce v. Gentsch, 141 F2d 
mandatory penalty is levied where no return is filed, ${ }^{13}$ reasonable cause will excuse penalties for belated returns. ${ }^{14}$

Even if the proper official had been consulted in the Stockstrom case, the objectives of the filing requirements might not have been satisfied. A tax return is intended to make available all essential information in permanent form. The Bureau may have no record of information given orally. If an agent forgets information or resigns his post, later review of his decision might be impossible. Opportunity for such review is necessary for checking the accuracy and honesty of officials and also for making redeterminations of liability should statutory interpretations change. ${ }^{16}$

The Court of Appeals was untroubled by the possible lack of records since it held that the Internal Revenue Code requires the collector to file a return for errant taxpayers. ${ }^{16}$ This interpretation of the Code is questionable. Probably the Code rule was intended merely to give collectors permission to file returns for taxpayers in order to utilize ordinary administrative machinery

891 (6th Cir. 1944) (taxpayer overthrows agreement successfully). Sce GoodkIcn AND Redman, Procedure Before the Bureau of Internal Revenue 88 (1951); Gutkin, Informal Federal Tax Settlements and Their Binding Effect, 4 TAx L. REv. 477 (1949).

13. INT. Rev. Code $\S 3612$ (d). See, e.g., Block Co., Inc. v. Commissioner, 12 T.C. 366 (1949) (penalty levied even where taxpayer relied on advice from collector's office and did not file a return).

14. INT. REv. CODE $\S 291$. Even where returns are years late, a good excuse will generally prevent the assessment of a penalty for failure to file on time. Reliance on the advice of a CPA to whom all information had been given is reasonable cause. Haywood v. Commissioner, 178 F.2d 769 (2d Cir. 1950). Belief based on reasonable cause may defeat the penalty. Economy Savings \& Loan Co. v. Commissioner, 158 F.2d 472 (6th Cir. 1946). Advice from tax experts may also be a sufficient excuse. Reliance v. Commissioner, 15 T.C. 604 (1950). See Spies v. United States, 317 U.S. 492, 496 (1943) (penalty not aimed at innocent errors). But of. Credit Bureau v. Commissioner, 162 F.2d 7 (2nd Cir. 1947) (mere belief is insufficient excuse). See generally Katmens \& Ancier, What Constitutes Reasonable Cause?, 30 TAxes 58 (1952).

15. The Commissioner is free to re-examine and re-establish tax liability unless barred by limitations or a binding settlement. Blackhawk-Perry Corp. v. Commissioner, 182 F.2d 319 (8th Cir. 1950), cert. denied, 340 U.S. 875 (1950); Okonite v. Commissioner, 155 F.2d 248 (3rd Cir. 1946), cert. denied, 329 U.S. 764 (1947); Barry v. Westover, 70 F. Supp. 537, 546 (S.D. Cal. 1947). The Commissioner may even decide that a refund was erroneously awarded. Page v. LaFayette Worsted, 66 F.2d 339 (1st Cir. 1933), cert. denied, 290 U.S. 692 (1933).

All tax returns filed with the Bureau are subject to re-examination by random sampling. In addition, audits of certain classes of returns are made on a regular cyclical basis. Thus a "three year cycle applied to professional persons would require that such taxpayers be audited once in three years." Spencer, Tax Practice and Procedure in the Collectors' Office, 30 TAXES 120, 122 (1952). Moreover, returns are listed and indexed to permit the observance of transactions extending over a period of years. Id. at 120 . Indices and other records are prepared from returns each year. Round Table on Collection Procedures, 5 TAx L. REv. 481, 485, 491 (1950). These may facilitate cxaminations of returns when statutory interpretations shift. However, too few offices maintain a permanent system of index cards. Id. at 485 .

16. INT. Rev. Code § 3612. See note 8 supra. 
in processing information. ${ }^{17}$ Moreover, requiring the collector to file a return in every case where he acquires information may impose an unnecessary and perhaps burdensome duty. Possibly the collector would have to make a return whenever a request for a ruling was received, for these requests must contain all material facts. ${ }^{18}$ It is conceivable that collectors would have to make out returns on the basis of employers' and donees' information returns whenever a listed individual failed to file his own return. ${ }^{19}$ Although even the Stock-

17. "This [\$ 3612] means the authority to investigate those who have filed no return; to examine those who have filed incorrect returns; and to make a tentative tax determination, subject to approval by the Commissioner." THE Work Aro Jurssorctron of the Bureau of Internal Revenue 93 (194S) (prepared under the direction of the Commissioner of Internal Revenue). The permissive nature of this authority is emphasized. Id, at 94.

This section of the Code originated in Revised Statute 3176 (1875) which was in force at a time when problems of tax administration were far simpler than the present. Formerly federal assistant assessors were required to prosecd through their respective districts and enumerate objects of tavation by investigating ovners of property. Renfield, Handboor of United States Tax Law 14 (1863). This duty was given to collectors. Rev. Stat. 3172 (1875). In the period between the Civil War and World War I, nearly all national revenue was raised through customs duties and excise taxes. Green, Theory and Practice of Modern Taxation $S$ (1938); 26 Eitcrclogzola AMIERTCANA 293b (1948). Between 1870 and 1900, internal revenue was the source of less than half the small national revenue. The Statistrcal Adstract of tae Usirno States 163 (1935). Taxes on spirits and tobacco were the principal sources of internal revenue. Id. at 174. In the complex tax structure of today, it is impossible for collectors to move through the districts and question every taxpayer. Accordingly, the modern system is characterized as far as possible by self-assessment and self-collection. Rep. Atr'y Gen. Conrar. Ad. Proc, Mono. 22, p. 6 (1940). This places the primary responsibility on the taxpayer.

Prior to 1928, an assessment made without a return was considered illegal and void. Accordingly, returns were prepared by collectors where tax deficiencies were sought from taxpayers who had filed no returns. This procedure was rendered unnecessary in 1928. United States v. Haar, 27 F.2d 250 (5th Cir. 1928), cert. denicd, 278 U.S. 634 (1928). The general practice of preparing returns under $\$ 3612$ has been discontinued by the Bureau. Communication to the Yale Law Jounnal from E. I. McLarney, Deputy Commissioner of Internal Revenue, dated May 15, 1952, on file in Yale Law Library.

It is unclear whether a return filed by a collector will begin the running of the statute of limitations. The Tax Court has said that it lnows of no case so holding. Sec Estate of Henry Wilson v. Commissioner, 2 T.C. 1059, 1079 (1943). But sic Heffernan v. Alexander, 4S F.2d 855, 858 (W.D. Okla. 1931) (dictum that a return filed by a collector is as effective for beginning the limitations periad as a return filcd by a taxpayer).

18. For rulings on consummated transactions, the taxpayers must provide complete information with copies of each pertinent document and the names of all real parties in interest. 26 ConE FED. REGs. \$ 601.t(e) (3) (1949). For a detailed description of procedure to be followed, see 26 CODE FED. REGS. $\$ 601.15$ (income tax), $\$ 601.31$ (cstate and gift tax) (1949). Rulings may be requested in a restricted number of proposed transactions. 26 CODE FED. REGS. \$ 601.4(e) (1949). See Wenchel, Toxpaycrs' Restings, 5 TAX L. Rev. 105, 108 (1950); Richmond, Hon and JWlen to Ohtaju Burcas Rulisgs, 28 TAXes 45 (1950).

19. Information returns are required from donees and employers each year. These returns show the amount of income and the value of gifts. A large number of informa- 
stron court probably would not start the statute of limitations running if the information received were grossly incomplete or incorrect, ${ }^{20}$ collectors might feel obliged to file in most cases lest valid claims be lost.

Ad hoc attempts to make equitable decisions, of which Stockstrom is an example, should be kept to a minimum in the tax field. The vast number of taxpayers and the relatively small size of the Bureau require an exceptional degree of predictability and uniformity. ${ }^{21}$ The taxpayer can easily ensure the running of the statute of limitations by filing a proper return. ${ }^{22}$ He has complete access to the records and is concerned only with his own tax problem. Perfect accuracy or completeness in returns is not necessary to begin the limitations period if the return evidences a genuine effort to comply with the reventie laws. ${ }^{\text {ad }}$ Thus by a simple act of good faith the taxpayer can protect both himself and the public treasury.

tion returns are filed each year. The Bureau received in 1950 over 12 million information returns from employers for the withholding tax alone. ANN. REP. OF COMM. INT. REv. 15 (1951). The total number of information returns received by the Processing Division in 1948 was 140 million. Round Table on Collection Procedures, 5 TAx L. REv. 481, 516 (1949-1950). These information returns are used as a check on all individual returns, and an automatic audit follows if the information return and regular individual return do not agree. Goodrich \& Rednan, Procedures Before the Burenu of INTERNAL REVENUE 47 (1951). These returns perhaps contain enough facts to rcquirc collector's returns under the reasoning of Stockstrom.

20. See Estate of Fenry Wilson v. Commissioner, 2 T.C. 1059 (1943) (statute of limitations does not begin with collector's return if it is based upon inaccurate information amounting to fraud).

21. The Bureau of Internal Revenue each year receives, processes and stores over 200 million tax returns and associated documents. Report to the JotNT CoMnuTreE ON InTERNal Revenue Taxation by the Advisory Group (1948), qutoted at 5 TAX L. REv. 249 (1949-50). Income, estate and gift tax returns alone totalled 66 million in 1949 and 54 million in 1950. ANN. Rep. of CoMm. INT. REv. 24 (1951).

As of June 1951, total personnel of the Bureau of Internal Revenue numbered in excess of 57,000 . Of these, only 4030 were in Washington. ANN. REP. OF CoMM. INT. REv. 5 (1952).

22. See note 1 supra. Filing a return shifts the responsibility for further action to the Commissioner. See generally Goodrich \& Redman, Procedure Before the Burenu of Internal Revenue (1951); Round Table on Collection Procedures, 5 Tax L. Rev. 481 (1950).

23. Zellerbach v. Helvering, 293 U.S. 172, 180 (1934). Sce Commissioner v. Mnookin's Estate, 184 F.2d 89, 93 (8th Cir. 1950) (mistaken omission does not prevent the running of the statute of limitations); Alkire v. Nicholas, 114 F.2d 607 (10th Cir. 1940) (since a return must substantially comply with requirements that essential informita tion be disclosed, a misleading return is insufficient to start the statutory period). 